\title{
LANDSCAPE GEOMORPHOLOGICAL EVOLUTION AND COASTAL CHANGES: A CASE STUDY OF COASTAL EVOLUTION IN THE WESTERN PATRAIKOS GULF AREA, WESTERN GREECE
}

\author{
Alevizos G. ${ }^{1}$ and Stamatopoulos L. ${ }^{1}$ \\ ${ }^{1}$ University of Patras, Department of Geology, Patras Hellas, University Campus, 26504 Rio \\ Achaia,geoalevizos@upatras.gr,leonstan@upatras.gr
}

\begin{abstract}
Geological and geomorphological research has been carried out in the western part of the south coast of Patraikos Gulf and the findings were studied in relation to archaeological remains found in the same area. The characteristics of the archaeological findings and the stratigraphical record and the deposits in which they are contained, may originate their source, transportation way and age.

The artifacts were contained in fluvial and alluvial deposits under the present land surface. Their age was estimated by archaeologists to be between $7^{\text {th }}$ century BC and $4^{\text {th }}$ century AC. Geomorphology and archaeology have strong historical and methodological links and can provide information about the processes and extent of environmental changes. They also provide the tools for analysing sedimentation rates, relative chronology and geomorphological evaluation of the particular archaeological site as well as clues for land-surface development, paleoenvironmental and climatic conditions. Sediments indicating considerable climatic changes in current humid areas are alluvial deposits of considerable thickness, covering areas with human activity. There is a close correlation, as shown by the archaeological findings between climatic and environmental fluctuations. Since when there is a transition in climatic conditions causing changes in hydrologic conditions with ensuing geomorphological instability and burying the structures.

Keywords: Geo-Archaeology, Holocene, Climate Change, Fluvial Geomorphology, Hellenistic Period.
\end{abstract}

\section{Пврі́ $\eta \psi \eta$}

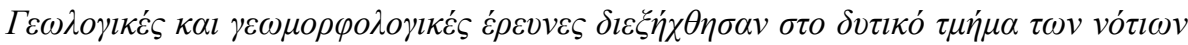

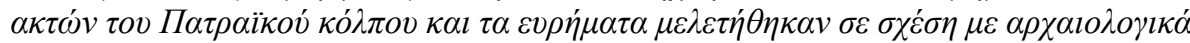

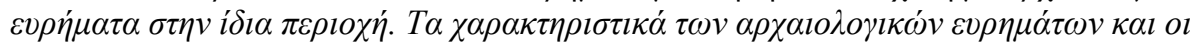

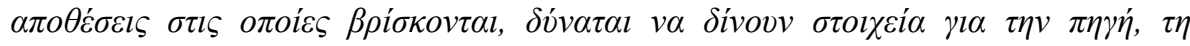

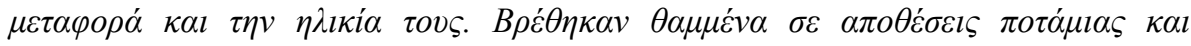

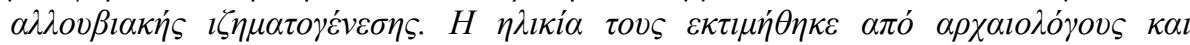

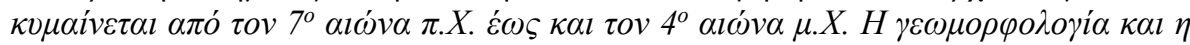

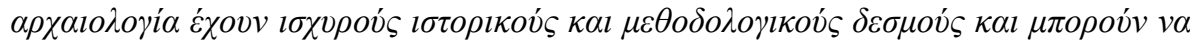

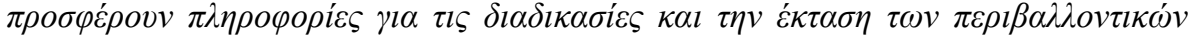
$\alpha \lambda \lambda \alpha \gamma \omega \dot{v}$.

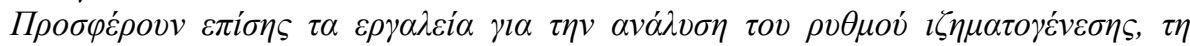

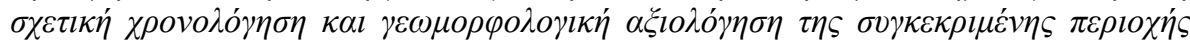




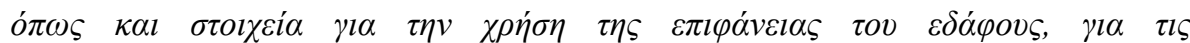

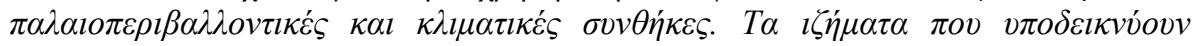

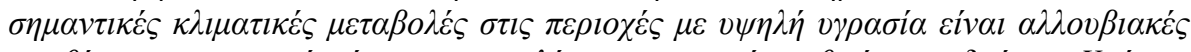

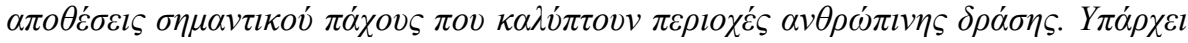

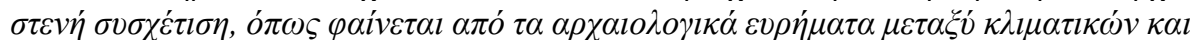

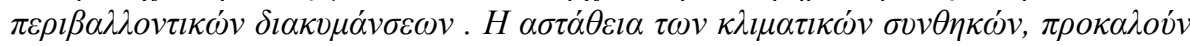

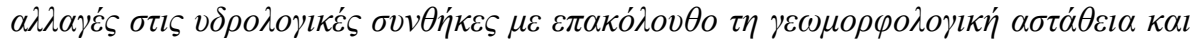
$\tau \eta \tau \alpha \varphi \dot{\eta} \tau \omega v \kappa \alpha \tau \alpha \sigma \kappa \varepsilon v \omega ́ v$.

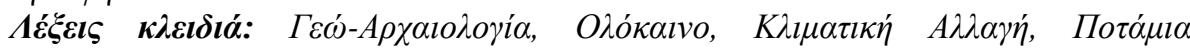

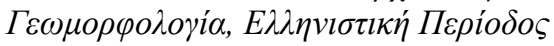

\section{Introduction}

The Patraikos Gulf forms the western end of a major east-west graben system, extending from the Ionian Sea through the Gulf of Corinth to the Aegean Sea. Major geomorphological and geotectonic events as well as human activity, characterise the evolution of this region in the Holocene (Dufaure et al., 1975; Piper and Panagos, 1979).

For a long length of time man's ability to alter the environment according to everyday needs, was limited by poor technological development and low population. The prevailing farming and breeding activities were conditioned by the natural context and, in turn, conditioned it. By means of constant and gradual interventions, natural hazards were progressively reduced and natural resources more and more exploited for economic purposes (Castaldini et al., 2007). The improvement of the living conditions in the town and its surrounding territory is mainly linked to reduction of the hygienicsanitary deterioration (produced on the environment by human settlements) and to water control. These interventions effects, combined with natural evolution, have contributed to create the present geomorphological situation. During the Early-Middle Holocene, human activities were strongly influenced by climate-induced environment changes, as evidenced by the occurrence of archaeological sites buried at different levels within the fluvial and alluvial deposits close to the coast.

Detailed field investigations of Holocene stratigraphy in combination with the study of an important number of archaeological discoveries provided valuable information for a better understanding of the relationship between man and the environmental change. During the Early-Middle Holocene, human activities were strongly influenced by climate-induced environment changes, as evidenced by the occurrence of archaeological sites buried at different levels within the fluvial and alluvial deposits close to the coast.

The wider region of the southern coast of Patraikos Gulf is characterised by a plethora of archaeological findings buried in fluvial and alluvial sediments. One common way of archaeology to be a tool in geomorphology, is by dating sedimentation or erosion and thereby establishing rates of flux, or dating the archaeological findings in order to identify and date major climatic events. Artefacts can give geomorphologists a datum point and sometimes a date, sometimes relative but sometimes more precise (e.g., from inscriptions) (Castaldini et al., 2007).

The discovery of archaeological evidence is an indication of a function of an environmental system behaviour and a challenge for scientists to interpret.

The main objective of this paper is to combine the archaeological information and environmental development in a direct chronological framework, to outline the geomorphological changes and to interpret the geomorphological evolution of the study area during the Holocene by associating these changes with archaeological, stratigraphical and geomorphological findings obtained from fieldwork studies. 


\section{Methodology}

To study landscape evolution of the selected area, geological, lithological and hydrological data were compiled and separately analysed. A geomorphological survey was carried-out, which supplied an overview of the forms and processes, namely the geomorphological dynamics of the investigated area. As concerns geomorphological investigations, in this study, the data were primarily collected by means of bibliographical research, aerial photo interpretation and field survey.

Detailed field investigation of Holocene stratigraphy, coupled with the study of a large number of archaeological sites provided valuable information to better understand the relationships between man and the environment in the study area.

\section{Geographical and Geological setting}

The Patraikos Gulf located on the northwestern part of Peloponnese, lies approximately $100 \mathrm{~km}$ east of the Hellenic trench, immediately behind the Plioquaternary fold belt, which runs parallel to the coast of western Greece (Doutsos et al., 1987). The mountains of Klokova and Varasova are located to the northeast of the Gulf, consisted of Cretaceous limestones and Eocene flysch (Gavrovo zone). Quaternary deltaic deposits of Acheloos and Evinos rivers are located to the northwest, while the southern shore of the Gulf is characterized by Plio-Quaternary deposits of shallow marine and lagoonal origin (Piper and Panagos, 1981; Hageman, 1977; Mariolakos and Papanikolaou, 1982). It comprises a thick Upper Tertiary clastic sequence, which overlies unconformably the pre-Neogene basement (Zelilidis et al., 1988). The geomorphological features of the area are influenced by bedrock structure, crustal movements and Quaternary climate changes.

The study area has an altitude that ranges from 0-70m (Figure 1) and mainly consists of semiconsolidated Neogene sediments or Quaternary fluvial, alluvial and overbank deposits.

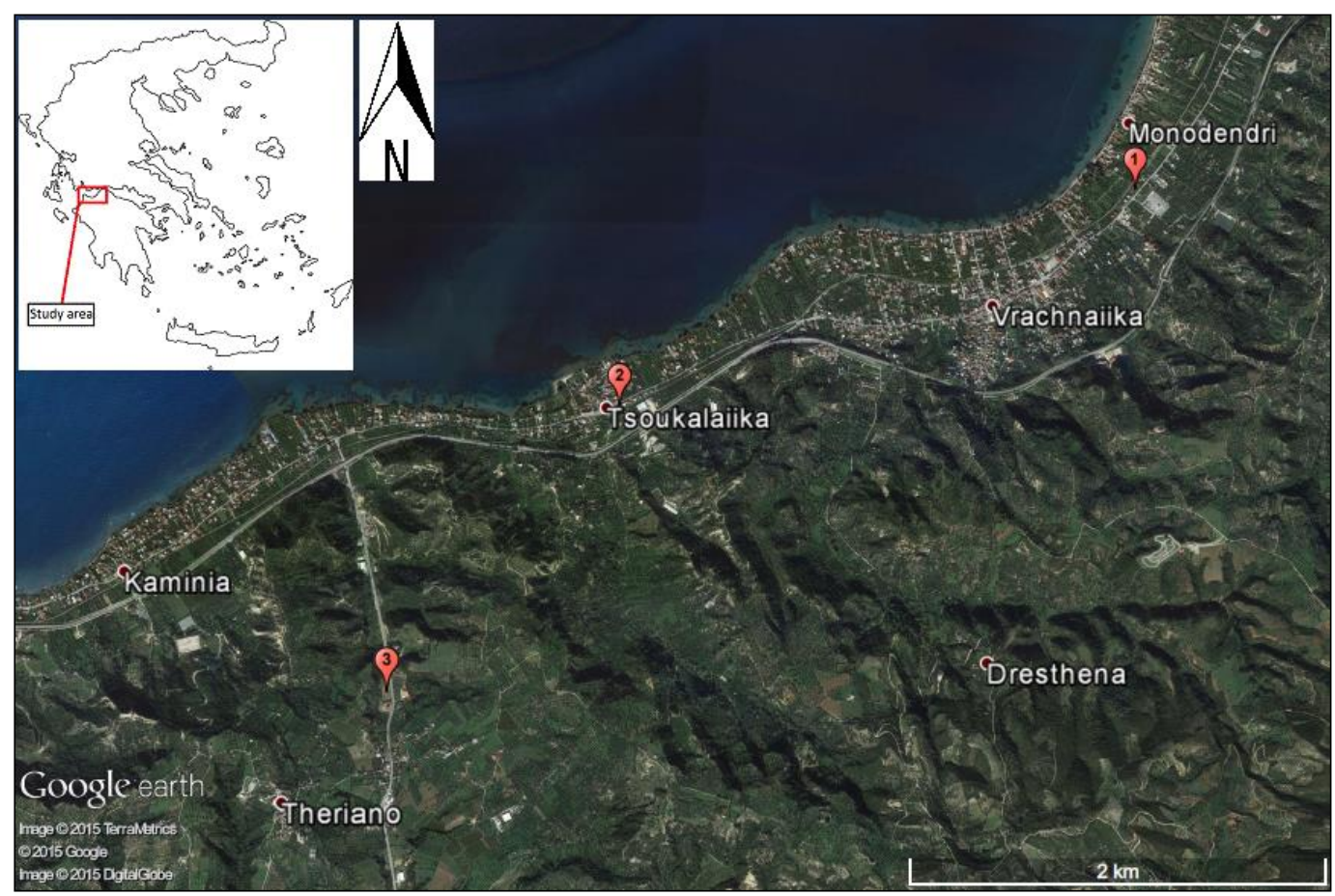

Figure 1 - Location of the study area with marked red (1-3) archaeological locations (Google Earth/Terrametrics/DigitalGlobe). 
From a tectonic point of view, Patraikos Gulf area consists the western part of a major East/West graben system, behind the Plioquaternary fold belt (Doutsos et al., 1987). This graben system extends from the boundary of a marginal compressional zone (Brooks and Ferentinos, 1984) associated with the subducting Western Hellenic arc, to the center of the Aegean Sea (Figure 2).

The study area is located at the western part of the southern coast of Patraikos Gulf, with Neogene folded rocks of Araxos to the West, Skolis mountain to the south and Panachaiko mountain to the east.

The WNW-ESE trending grabens of this system (Gulf of Corinth and Megara Basin) are associated with listric normal faulting (Zelilidis et al., 1988) trending at the same direction and are associated with shallow earthquakes (Brooks and Ferentinos, 1984; Jackson et al. 1982). The trending WNW subsiding areas in the immediate vicinity, like the Prevesa Gulf, Trihonis lake and the Corinthian Gulf are also associated with ENE trending faults (Doutsos et al., 1985) (Figure 2).

\section{Archaeological evidence and sedimentary record}

The evolution of the coastal environment is the main key for understanding the history of the archaeological evidence in the area. During Holocene, human groups more or less continuously occupied the study area. Recurrent flooding episodes repeatedly buried these sites under fluvial and alluvial sediments.

These deposits consist of alternating beds of very fine greyish sand, silt and silty clay with occasional lenses of fine to medium gravel and cobbles for the Vrachneika area (No.1) and laminations of very fine to coarse grained sand, silty sand, sandy silt and clay with occasional fine to medium gravel and cobbles for the Tsoukaleika and Theriano area (No. 2 and 3).

At present times, human activity in the three marked areas (Figures 1 and 2) have revealed archaeological artefacts. The interaction between geomorphology and archaeology in the Modena territory show the significance of the relationship between human communities and nature. It also shows the effect these communities had on the territory from the $8^{\text {th }}$ century B.C. onwards.

Excavations that were carried out, revealed a great total number and variety of findings in all three areas, showing an extensive human activity taking place in the general study area.

The area is characterized by a wide variety of archaeological findings, including several pottery artefacts, settlement remains, a sanctuary, a Roman cemetery, a sanctuary and Roman baths buried at depths of $0.3-5 \mathrm{~m}$ bellow and between fluvial, alluvial and flash flood sediments.

\section{Discussion}

The geomorphological characteristics of the study area are mainly the result of the fluvial, alluvial and tectonic evolution in combination with human activity. The geomorphological information was obtained from field survey, aerial photo-interpretation and bibliographic research and from the analysis of other maps (micro-relief, surface deposits). During the Würm Pleniglacial (ca. 30,00015,000 B.P.), the study area was generally affected by dry-cold climate conditions which favored frost shattering on limestone and flysch slopes and related production of significant amounts of debris, which were subsequently moved down to the river channels by running water and mass movements, causing stream overcharging and riverbed aggradation (Calderoni et al., 2007).

Subsequently, in the early Holocene underwent a rapid change of climate, characterised by humidtemperate conditions and a widespread development of vegetation, that drastically reduced slope erosion and riverbed aggradation, favoring the incision of the previous alluvial sediments (Castaldini et al., 2007). From 3.500 B.P. to post-Roman times, fluvial erosion dominated almost everywhere in the central Marches, with the development of slowly deepening sinuous or meandering channels. 
Examining the system of faults in the vicinity, the presence of a more or less continuous, pre-existing fault scarp is being deduced (Figure 2) that due to wave erosion and tectonics, has retreated. This retreat is underlining the problem of the coastal area of Achaia, hence western Achaia as well, which is facing a major coastal erosion problem due to climatic change.

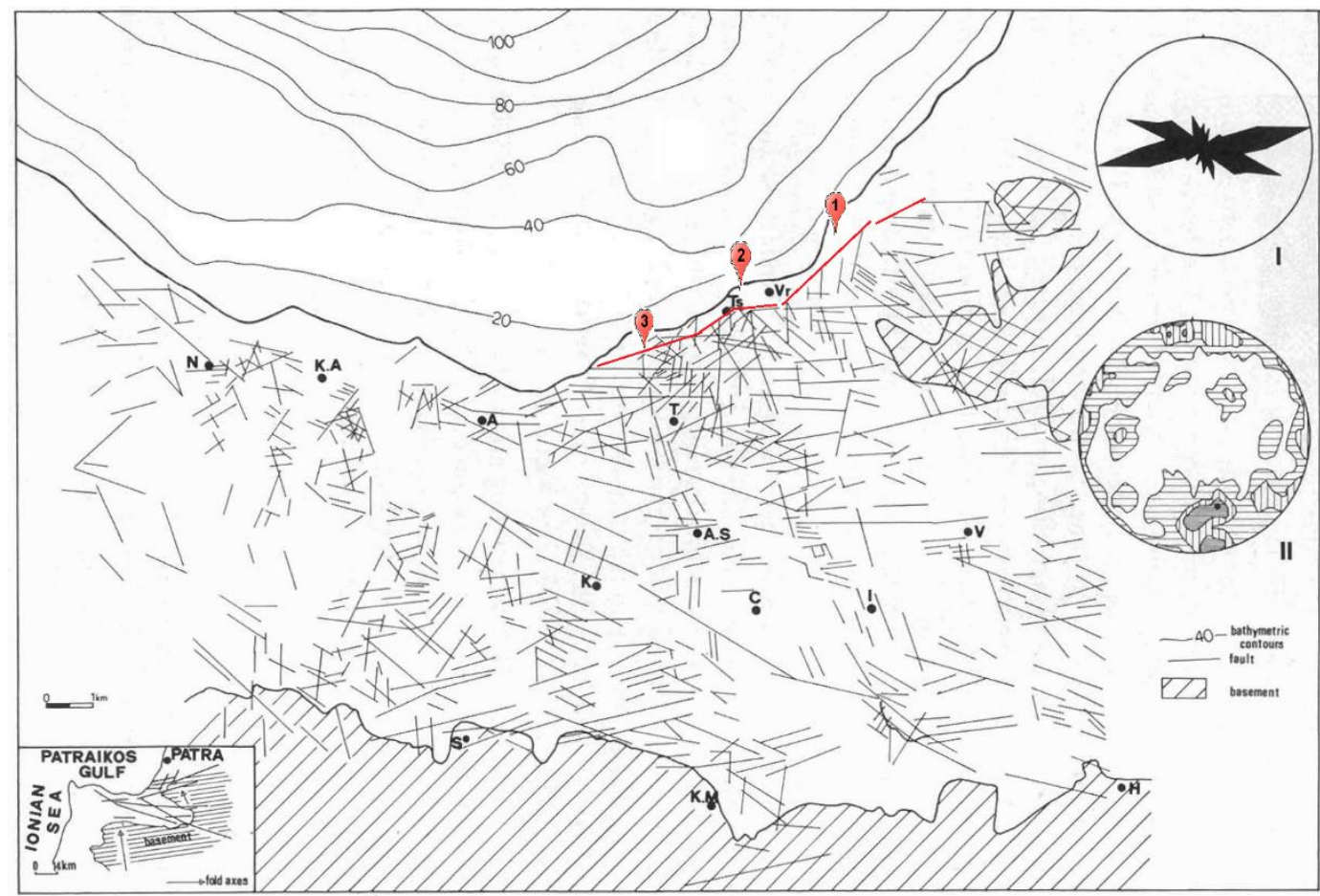

Figure 2 - Faults of the graben system related to the Patraikos Gulf (Zelilidis et al., 1988) (modified). Red line shows the trace of the pre-existing active fault scarp.

Moreover, the earthquake of 2008 in the neighboring area of Movri has created several surface cracks which probably indicate the presence of the scarp and in places indicate the presence of fault lines (Stamatopoulos, L., personal communication, December 4, 2015). The existence of this, active in the late Quaternary, scarp is supported by some surface scarps in the Saravali area, the trend of the coast line and the trend of the bathymetric lines near Vrachneika village (Zelilidis et al., 1988).

Also, the large-scale uplift which has occurred during the Plio-Quaternary in northern Peloponnese which has also played a significant morphogenetic role in the area (Stamatopoulos and Evelpidou, 2011), created even more sedimentary material and flooding events and sediment deposition on the river sides were increased.

From a methodological standpoint, though, a definition of the relationship between fluvial forms and archaeological sites cannot be expressed by a simple presence/absence ratio. The presence of archaeological findings overlapping landforms identifies, as a rule, an ante quem dating, whereas an opposite relation, that is a landform overlapping buried archaeological findings, is identifiable with a post quem dating.

The wider Patraikos Gulf area in northern Peloponnese is characterised by the presence of plenty archaeological findings, mainly of Early to Late Protogeometric Period to Late Archaic due to the occupation of the area from productive human groups. Recurrent flooding episodes repeatedly buried these sites under fluvial and alluvial sediments. Also, according to the examined sediment 
particle size and the lens type of its formation, some flash flooding events in ephemeral river channels must have taken place.

Three areas of archaeological interest (Marked 1-3 in the respective Figures 1 and 2) are described as an indicative example of the extensive human activity in the area. Archaeologists estimated the age of all artefacts and found that for area No.1 the stone graves revealed are dated around $1^{\text {st }}$ century B.C. (Roman Greece) while for area No.2 some Roman baths were discovered and they divided the findings into two distinct periods.

The first one is between late $1^{\text {st }}$ century B.C. (Roman Greece) and $4^{\text {th }}$ century A.C. (Late Antiquity period) while the second is dated between $3^{\text {rd }}$ century B.C. (Hellenistic Period) and the middle of $1^{\text {st }}$ century B.C. (Roman Greece) buried under overbank deposits (Figure 3) (Tsakirakis, 2009).

Area No. 3 showed archaeological evidence of a sanctuary, dated as of late $8^{\text {th }}$ century B.C. - early $7^{\text {th }}$ century B.C. and more likely around 700 B.C. (Late Geometric - Late Archaic Period) (Figure 4) (Tsakirakis, 2009).

The impact of man-made forest clearance and agriculture, which has progressively spread all over the area since the Iron Age, does not seem to have significantly affected fluvial erosion-deposition processes, as suggested by the generalized deepening trend of river channels in the general study area up to recent historical times.

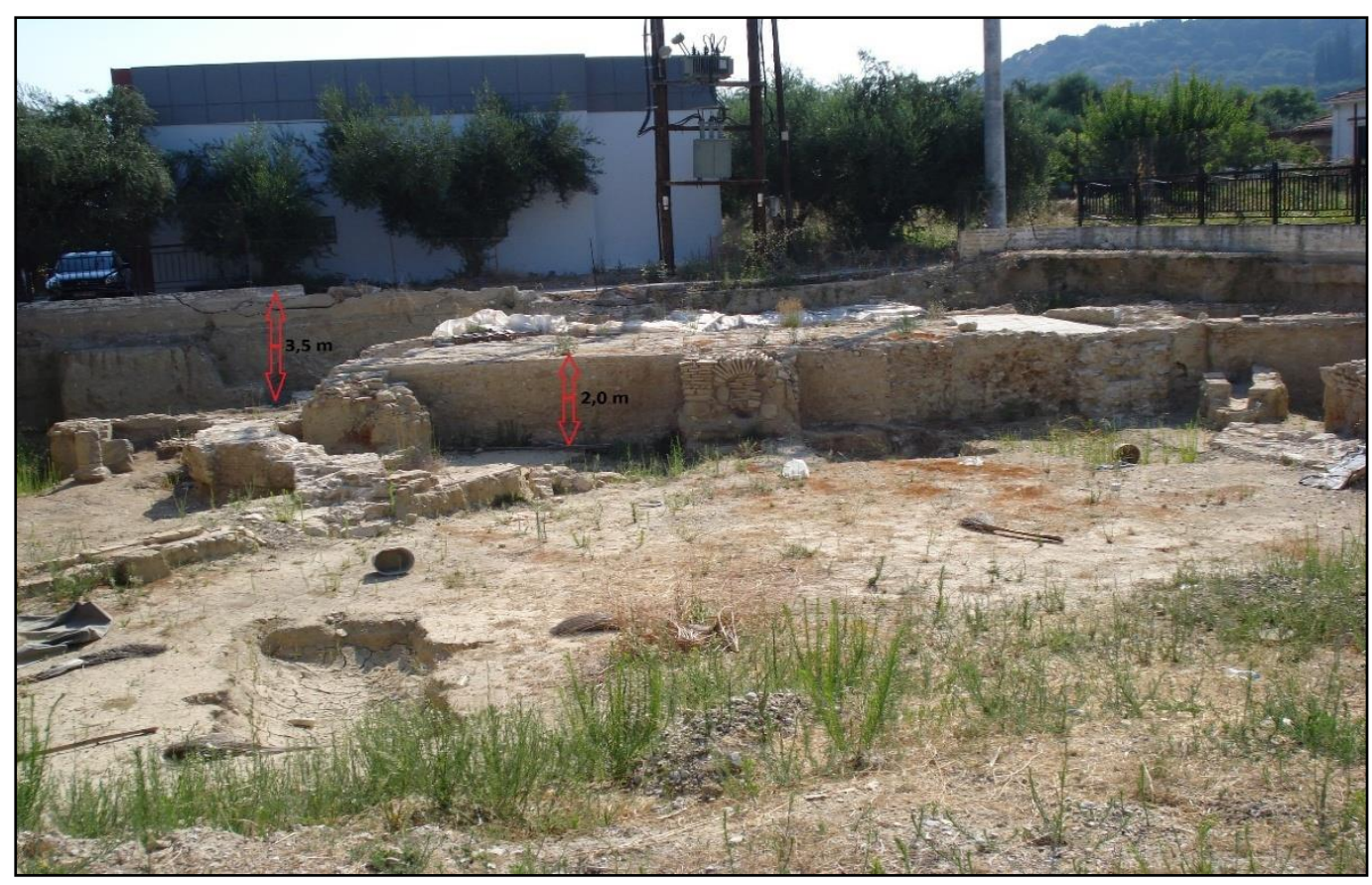

Figure 3 - Partial view of the archaeological findings of Roman baths at Tsoukaleika area (Area No.2). Red arrows indicate the height of the discovered structure and the depth of the excavation. 


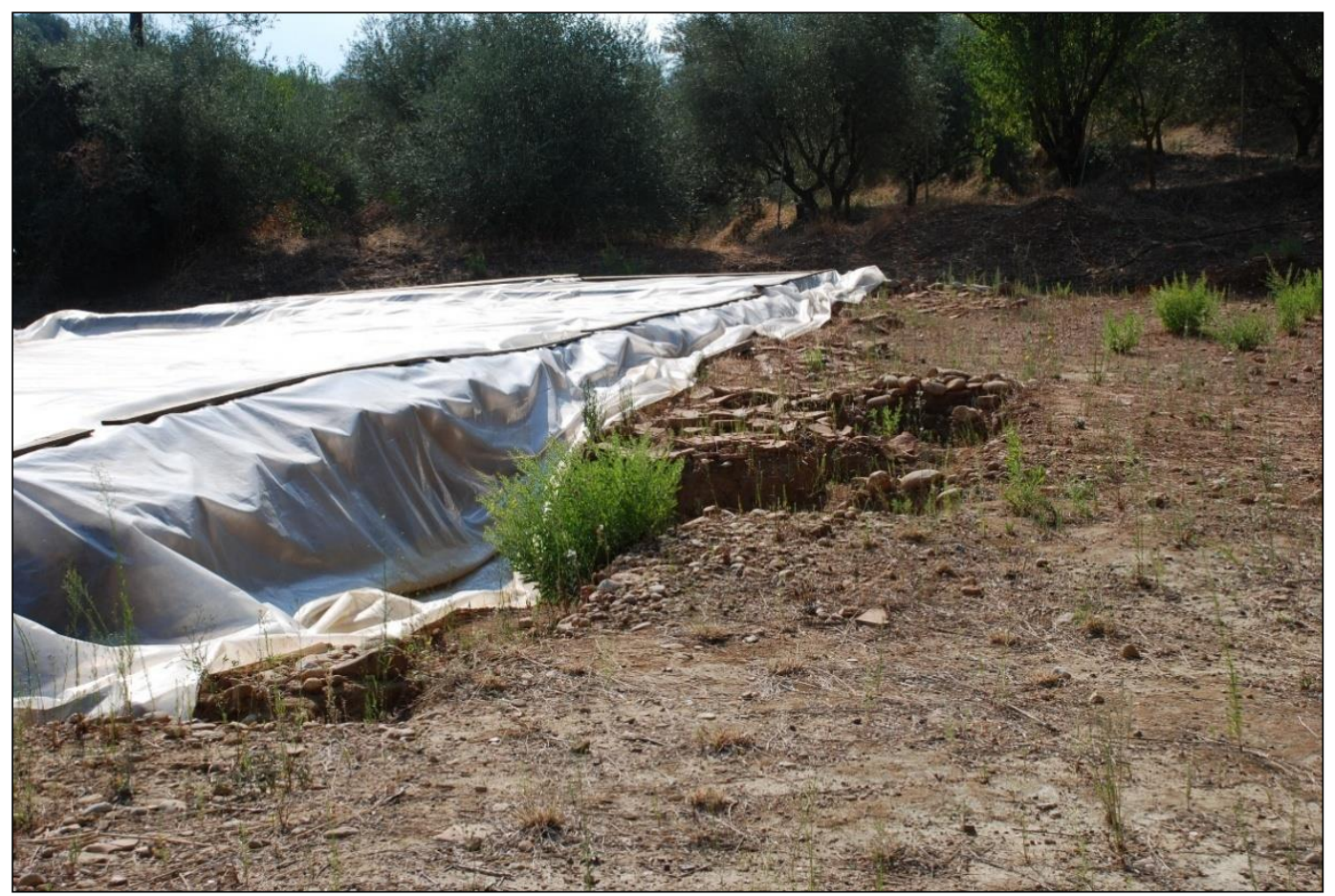

Figure 4 - Partial view of the archaeological findings of the sanctuary at Theriano area (Area No.3).

\section{Conclusions}

The southern coast of the Gulf of Patras, provides a typical example of climate-induced environmental changes which have, in turn, affected the human communities and structures present in the area.

The geomorphological evolution is one of the main keys for understanding the history of human settlements in general study area. From the $8^{\text {th }}$ century B.C. to post-Roman times notwithstanding the progressive spreading of agricultural-pastoral activities all over the area and the related increase of debris supply to the drainage systems, erosion and deposition processes dominated almost everywhere in the rivers of the Patraikos Gulf, likely induced by climatic factors.

The large-scale uplift which has occurred during the Plio-Quaternary in northern Peloponnese created an aggradational type of fluvial evolution. This hypothesis was modeled according to the reconstruction of figure 5. According to this model, the watercourses, even the minor ephemeral ones, passed from a runoff occurring in deep riverbeds to one elevated after passing the pre-existing scarp with respect to, or at least at the same level as, the surrounding plain within embankments. The alluvial fan was created due to the change of gradient when the watercourse is exiting the fault scarp area. This model represents the buried archaeological findings in the areas 1 and 2 (Vrachneika and Tsoukaleika). In contrast, in area 3 (Kaminia) the sediments are exclusively of fluvial processes.

Human life, in the early- middle Holocene was controlled by erosion and deposition processes by ephemeral river channels and flooding events in the area, induced by climate changes. Moreover, the role of human impact on landscape evolution in the study area during the Early-Middle Holocene seems to be relatively limited.

Archaeologists dated the artefacts and their age varied from the $7^{\text {th }}$ century BC to the $4^{\text {th }}$ century AC, signifying major geomorphological and tectonic events. 
The tectonic environment of listric faults and the forming scarp on the south of the wider study area could also assist these events and provide excess of sedimentary material. That hypothesis is supported by the stratigraphy and the particle size of the sediments that the archaeological remains were buried in.

Lenses of larger particles in the generally fine matrix reveal some extreme flash flooding events. Human activity in the area appeared to be significant and the whole geomorphological environment played a significant role in forming their life conditions, their living places and generally their life patterns.

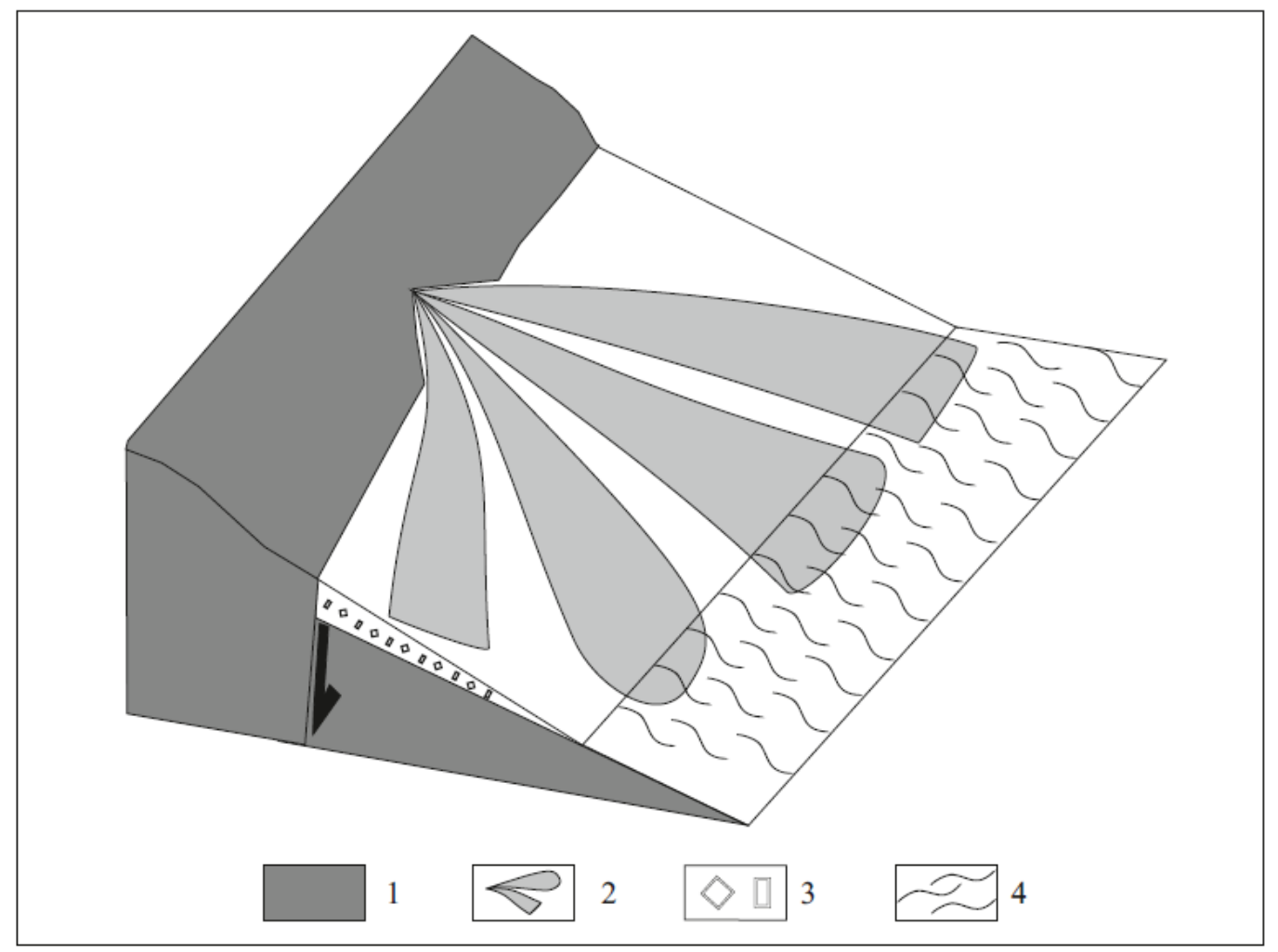

Figure 5 - Schematic illustration of the morphogenetic evolution of the study areas 1 and 2 (Vrachneika and Tsoukaleika). 1: Fluvial deposits. 2: Alluvial fan. 3: Archaeological findings. 4: Actual sea level.

\section{References}

Brooks, M. and Ferentinos, G., 1984. Tectonics and sedimentation in the Gulf of Corinth and the Zakynthos and Kefallinia Channels, western Greece, Tectonophysics, 101, 15-30.

Calderoni, G., Cilla, G., Dramis, F. and Gobbi, C., 2007. Georgaphie Physique et Environnement, 1, 21-32.

Castaldini, D., Cardarelly, A., Cattani, M., Panizza, M. and Piacentini, D., 2007. Georgaphie Physique et Environnement, 1, 33-56.

Doutsos, T., Kontopoulos, N. and Ferentinos, G., 1985. Das westliche Ende des Korinth- Grabens, N. Jb. Geol. Palaont. Mh., 11, 652-666.

Doutsos, T., Kontopoulos, N. and Frydas, D., 1987. Neotectonic evolution of northwestern continental Greece, Geol. Rdsch., 76, 433-450. 
Dufaure, J., Kadjer, M.H., Keraudren, B., Mercier, J.L., Sauvage, J. and Sebrier, M., 1975. Les deformations plio-pleistocene autour du golf de Corinthe, C. r. somn. Soc. Geol. Fr., 18-20.

Jackson, J., Cagnepain, J., Houseman, G., King, G., Papadimitriou, P., Soufleris, C. and Virieux, J., 1982. Seismicity, normal faulting and the geomorphological development of the Gulf of Corinth (Greece): The Corinth earthquakes of February and March 1981, Earth Planet. Sci. Lett. 57, 377-397.

Hageman, J., 1977. Stratigraphy and sedimentary history of the Upper Cenozoic of the Pyrgos area (Western Peloponnesos), Greece, Annals geol. Pays Hell., 22, 299-333.

Mariolakos, J. and Papanikolaou, D., 1982. The Neogene basins of the Aegean arc from the palaeogeographic and geodynamic point of view, Proceedings of the International Symposium on the Hellenic Arc and Trench (H.E.A.T.), II, 383-399.

Piper, D.J. and Panagos, A., 1979. Marine Geology of the Gulf of Patras, Thalassographica, 3, 5-20.

Piper, D.J. and Panagos, A., 1981. Growth patterns of the Acheloos and Evinos deltas, western Greece, Sediment. Geol., 28, 111-132.

Stamatopoulos, L. and Evelpidou, N., 2011. River-bed evolution during the Holocene in Kalavrita region (Northern Peloponnese, Greece), Revista de Geomorphologie, 13, 5-8.

Tsakirakis, V., 2009. Ancient times and middle ages.Vrachneika and Monodendri, Municipality of Vrachneika, 73-84, Taxytypo Press.

Zelilidis, A., Koukouvelas, I. and Doutsos, T., 1988. Neogene paleostress changes behind the forearc fold belt in the Patraikos Gulf area, western Greece, N. Jb. Geol. Palaont. Mh, H.5, 311-325. 